\title{
THE USE OF INFORMATION SYSTEMS FOR KNOWLEDGE MANAGEMENT IN SMALL TOURIST AGENCIES
}

\author{
Dean Nižetić, MSc \\ University of applied sciences VERN \\ Trg bana Josipa Jelačića 3, Zagreb, Croatia \\ e-mail: dean@nizetic.com \\ Anton Florijan Barišić, PhD, College Professor \\ University of applied sciences VERN \\ Trg bana Josipa Jelačića 3, Zagreb, Croatia \\ e-mail: afbarisic@chronos.hr
}

\begin{abstract}
Rapid development of technologies led to emergence of new opportunities for businesses such as effective management of knowledge resources for achieving organizational performance. The purpose of this paper was to determine whether the agencies are using KM systems available on the market, what are the reasons for their adoption, and explore the adequacy of implemented systems, and to define the characteristics of "ideal" KM systems for small organizations. In that sense, the main goal of the research was to explore the adoption degree of information technology for knowledge management in small tourist agencies with fewer than 20 employees. Based on survey among small tourist agencies conducted upon the sample of 68 usable responses from on-line questionnaire, this research outlines position and development trends in using information systems for knowledge management answering following questions: (a) Do agencies recognize the benefits of using knowledge management systems and in which segments of their business?: (b) What types of knowledge management systems they use and in which business segments?: (c) What are the reasons that agencies may not use knowledge management systems? In the research, the mathematical-statistical methods have been used, in order to analyse the attitude of the small Croatian tourist businesses toward usage of modern technologies to bust their business performances. The results also have indicated the reasons for low adoption of IT KM solutions in their everyday business operations. Based on the conducted analysis, a framework specification of an "ideal" KM system has been suggested.
\end{abstract}

Keywords: IT management; knowledge management; organisation; organisational performance; organizational effectiveness 


\section{INTRODUCTION}

According to Weaver, \& Oppermann, (2000, p.20), tourism may be defined as "the sum of the phenomena and relationships arising from the interaction of tourists, business suppliers, host governments, and host communities in the process of attracting and hosting these tourists and other visitors". It can be described as an industry that delivers a travel experience for individuals or groups in terms of transportation, accommodations, eating and drinking establishments, shops, entertainment, leisure and sport facilities and other hospitality services. It encompasses all guests and visitor providers and guest related services (Asll, 2007; North, 2008; Dalkir, 2013).

The tourist and hospitality industry provides services with the primary objectives to satisfy the travel and accommodation demands. Striving to make their final product available to guests of all kind and wherever, tourist organizations cooperate with many different service providers, such as event and entertainment organizers, tour operators, transporters, shopping centres, etc. (North, 2008; Musulin, Gamulin \& Crnojevac, 2011). The common denominator for all these service providers is that their businesses are knowledge based. Due to the high degree of adoption and use of ICT and the essential features of the tourist services, the entire industry is becoming knowledge-intensive (North, Reinhardt and Schmidt, 2004; Barišić, 2013). Therefore, for tourist organizations, the creation and utilisation of new knowledge to enable product and service innovation and development is essential for achieving the competitive advantage (Ciampi, 2007; Buhalis \& Law, 2008).

According to data published by the Ministry of Tourism of the Republic of Croatia, in 2017, tourism in Croatia generated the revenue of 9.49 billion HRK, which represents a share of $19.6 \%$ in the total gross domestic product, which amounted to HRK 48.46 billion for the same year (Ministartsvo turizma Republike Hrvatske, 2018, p. 43). The above data indicate the importance of tourism industry for the overall Croatian economy, but it certainly made sense of the level of competition in the surrounding countries in which the travel agencies operate in their efforts to gain and retain their clients. Considering the complex and heterogeneous nature of the tourist industry and its inherent qualities, the data management and knowledge transfer is of ultimate significance (Kakihara \& Sørensen, 2002; Casimir Lee, \& Loon, 2012). The importance of the information and knowledge management, especially in the field of tourism, was evidenced by the understanding of the destination organization responsible for managing the destination (Tourist boards), as an information broker collecting information on tourism resources, products and services, and market opportunities (World Tourism Organization, 2007, p. 125). Therefore, knowledge and information management as a concept, to tourist industry becomes not only a way to gain market advantage, but a real necessity for a successful presence on the world market (Weaver, 2000; Zaei \& Zaei, 2014).

\section{KNOWLEDGE MANAGEMENT (KM)}

As a fundamental resource, knowledge can be also described in terms of the insights, acumen, observation, familiar, understandings, and practical know-how. Omona, van der Weide \& Lubega, (2010) and Tribe \& Liburd, (2016), argue that gaining the knowledge as an intangible asset requires "complex cognitive processes of perception, learning, commu- 
nication, association and reasoning." The literature related to the knowledge management separate knowledge from knowing. Knowledge generally, is considered as theoretical knowledge or explicit knowledge easy to be managed, while knowing is a practical knowledge related to one's experiences, skills and competences and thus difficult to manage (La Rocca, 2012; Casimir, Lee \& Loon, 2012; Omotayo, 2015). Regarding organisations, the knowledge is incorporated and recorded not exclusively in manuscripts but also in organisational culture, standards and values, routines, practices and processes (Cooper, 2006; La Rocca, 2012; Tribe \& Liburd, 2016).

In that sense, KM is an important enabler of advanced organisational accomplishment and effectiveness and a fundamental organisation's resource to handle the challenges of globalized competition, information and knowledge transformation, vigorous and vibrant product innovations processes and process reengineering requirements (Hallin and Marnburg, 2008; Omotayo, 2015). Organisations that utilise KM in their operations to define strategies and identify resources for their successful realisation are more innovative and demonstrate better performance (Mistilis \& Sheldon, 2006; Livi, 2008; Maier \& Hadrich, 2011).

The importance of knowledge management is widely recognised also among all the industry sectors and not only within knowledge intensive industries. Tourist organisations also lay the basis for their success on utilisation of their knowledge-based assets (Assl, 2007; Livi, 2008; Omotayo, 2015). The knowledge management practice in the organization executes procedures of scheduling, categorizing, encouraging, and managing employees, procedures and structures, developing methodologies and systems to support those processes (Baggio \& Cooper, 2010; Del Chiappa \& Baggio, 2015).

Knowledge can be considered on many different concepts such as object, interpretation, process or relationship (Kakihara and Sorensen, 2002; Handžić and Durmić, 2015). Knowledge Management (KM) can be understood as creation of knowledge repositories, enabling of knowledge acquisition; improvement of the knowledge transfer; and usage of knowledge as an asset (Scott \& Laws, 2006; Shaw \& Williams, 2009; Barisic, 2013). In ever increasing and discontinuous change of the business environment, the knowledge management enables organisation to successfully adapt their business processes and achieve sustainable competitive advantage. The tourist industry experiences these changes from both the supply side and behaviour of consumers (Wielicki \& Arendt, 2010; Maier \& Hadrich, 2011).

Knowledge management is defined as " $a$ set of processes of generating, identification, gathering, processing and sharing of individual and collective knowledge with employment of information technologies" (Ciampi, 2007). According to OECD (2001) "creating, sharing, and using of knowledge is a critical factor of growth and changes, that are essential for innovative and knowledge economics". There is a pile of different definitions of knowledge and knowledge management. According to Girard and Girard, (2015), the incidence analysis of the 100 definitions of the knowledge management, discovered that the most common words appearing in KM definitions are: knowledge, organization, process, information, use, share, create and manage. Based on this survey, the following definition was proposed: "Knowledge Management is the process of creating, sharing, using and managing the knowledge and information in an organization" (Girard and Girard, 2015). 
In addition to the different KM definitions, there is a number of different concepts referring to knowledge classification:

- There is distinction between cognitive knowledge (know what), skills (know how), and system understanding (know why) (Mistilis \& Sheldon, 2006).

- The knowledge can be divided into several categories such as process, factual, catalogue and socio-cultural (Omona, van der Weide \& Lubega, 2010).

- The knowledge can be also classified as individual and collective category (La Rocca, 2012; Dalkir, 2013).

The majority of authors describe knowledge as implicit and explicit knowledge, where implicit (tacit) knowledge is individual knowledge caused by personal experience. The importance and pertinence of implicit knowledge increasingly grows referring to knowledge management and becomes one of key factors of organisational performance. Although the tourist organizations are abounding in tacit resources, it is often being ignored due to its complexity (Mistilis \& Sheldon, 2006; Casimir Lee, \& Loon, 2012).

Explicit knowledge is the knowledge that can be collected, stored, distributed and shared primarily in the form of electronic or paper documents and databases. Being easy to transfer and codify, explicit knowledge represents essential organisational infrastructure enabling organisations to perform their purpose and achieve business performance (Shaw \& Williams, 2009; Del Chiappa \& Baggio, 2015).

Above mentioned classification constitutes an important perspective for knowledge management in tourist industry, enabling it to identify, capture and transform implicit into explicit knowledge converting it into competences for the tourist industry endeavours (Scott \& Laws, 2006; La Rocca, 2012).

The tourist and leisure industry recognizes different dimensions of knowledge in the tourism and leisure industry such as task specific knowledge, task related knowledge, transactive memory, guest related knowledge, customer/supplier related knowledge, marketrelated knowledge and network-related knowledge (Weaver, 2000; Kakihara \& Sørensen, 2002; Musulin, Gamulin \& Crnojevac, 2011).

Task specific knowledge "contains the specific procedures, sequences, actions and strategies to fulfil a task", and can be recognized as both, explicit and tacit knowledge in executing business activities such as front and back office operations usually codified in manuals. Task related knowledge "contains individuals' shared knowledge not of a single task, but of related tasks, e.g. the form of teamwork in the firm" internalising similar working values such as shared quality standards, standardised products and services used in the form of the same layout of bills, guest requests, offers to clients, and values, norms and beliefs which represents organisation's culture (Maier \& Hadrich, 2011; Girard \& Girard, 2015).

Transactive memory "includes decentralised knowledge of the other organisational members' cognitive models." This form of knowledge dimension can be represented as yellow pages (finding the right expert for a certain knowledge needed) (Weaver, 2000; Zaei \& Zaei, 2014). Guest related knowledge is the core of tourist business (Livi, 2008; Maier \& Hadrich, 2011). It comprises socio-demographics, preferences, expectations, culture and other elements related to the knowledge of customers, but it should not only be based on demographic information (age, income, education, status or type of occupation, region 
of country and household size). It should include customers' lifestyles and behaviours and other intercultural aspects and differences in order to develop and offer the service package that best suit customer demands (Assl, 2007; Handžić and Durmić, 2015). The customer relationships and experience management is a part of the knowledge management concept.

Supplier related knowledge refers to the suppliers such as tourist offices, hotel chains, event and entertainment organizers, catering providers, etc., (Hallin \& Marnburg, 2008; Tribe \& Liburd, 2016), while market related knowledge in terms of size, population, culture, habits etc., is useful in adapting products and services to the preferences of the customers on specific tourist market (Cooper, 2006; Baggio \& Cooper, 2010). Network related knowledge as external knowledge helps organisations to recognize in what environment they operate, what are their competitors and how to establish relationships with other players as extremely important element of organisational performance on the target market, ensuring promotion of the organisation and long-term success (Ciampi, 2007; Hallin \& Marnburg, 2008).

\section{RESEARCH PROBLEM}

The purpose of the research was to determine how tourism, as a branch of the economy manages its knowledge. The research has been focused primarily on knowledge management through the support of information systems used by individual tourist organizations.

The main objective of the research was to conduct an analysis of systems in use in small tourist agencies, with a focus on the motivation for their use, the adequacy of the solutions used in respect of meeting the requirements in the context of the availability and accessibility of the existing knowledge. In that sense, an analysis of knowledge management systems tailored to the tourism business with special reference to the resources needed to introduce such systems (price, human resources, specialized knowledge required, etc.), has to be conducted. Given the research carried out, recommendations were to be made for the adoption of an "ideal" system that would meet the needs of small tourist agencies.

Based on the literature review and previous research, the following research hypotheses have been developed:

H 1: Knowledge and information management systems available to travel agencies are too expensive and over-priced for use in small travel agencies

Hypothesis 1 is based on the assumption that knowledge and information management systems available on the market come at the price that is significantly higher than agencies can afford in purchasing a KM system. The complexity of such systems may also constitute an impediment for agencies to use them, due to the lack of qualified human resources, because the agency staff primarily possesses the specialized "tourism" knowledge required to perform the core business activities.

H 2: Small travel agencies mainly use only very basic tools (Word, Excel, shared network space, etc.), but not knowledge and information management systems in any form.

Hypothesis 2 results directly from Hypothesis 1 . Basic office tools are easily accessible and available, and agency staff is generally using it at a level sufficient to carry out 
daily business activities. Because those tools are adopted in the early stage of the agency's existence, business growth and the increase of the number of employees is not significant to justify the replacement of basic tools by some specialized KM solutions.

H 3: The characteristics of an "ideal" knowledge management system intended for use in tourist agencies business could be defined to meet the requirements of small travel agencies.

Hypothesis 3 represents the assumption that it is possible to design a system that meets the needs of travel agencies and offers them more than the basic office tools, while being more affordable and easier to use than applications available on the market.

\section{METHODOLOGY}

As the survey sample, registered tourist or travel agencies with headquarters based in the Republic of Croatia have been selected. The number of employees has been used as the sample selection criterion, considering those agencies with 20 or fewer employees. For the purpose of the research the Google form questionnaire was compiled and distributed to the respondents using e-mail. The research covered 350 companies satisfying the criterion on the number of employees.

Sampling has been the subject of judgment of the researchers, which, of course, represents a limitation of this research considering the fact that the sample is not a representative sample of entire population of Croatian firms in that particular field. During the process of gathering the data, business registries and data bases have been used to collect the contact data of the managers of the small tourist or travel agencies. Erdogan and Tagg, (2003), have noted that any activity intended to motivate the respondents to fill in questionnaires increases the return rate. Therefore, the respondents were reminded through the phone calls.

The questionnaire contains 11 questions divided into 3 sections:

- Demographic questions

- Questions about the KM system/programme agency uses for business activities

- Questions about the "ideal", desirable KM system

The collected data were processed using statistical methods.

\section{RESEARCH RESULTS}

After the questionnaires were gathered, they were checked for their completeness and if the criteria regarding the number of employees were met. In that respect, it was established that there is only one questionnaire filled in by the company with more than 20 employees and one with a large number of missing answers. Those questionnaires were excluded from the analysis, and remaining 68 questionnaires were included in the process of the data entry and processing. Respecting the recommendation given by Wiseman and 
Billingtnon (1984), the return rate was calculated as the percentage of totally usable questionnaires and it showed that rate of return is $19.45 \%$ of the totally sent questionnaires.

Via online questionnaire, 68 valid responses have been collected $(N=68)$ from various agencies, which represents a significant sample for the purpose of the research. The research has been focused on small tourist agencies with 20 and fewer than 20 employees. Among the interviewed agencies, the most represented are the agencies with 3-5 employees, with the share of $40 \%(N=27)$ in the total population. They are followed by agencies having 6-9 employees, and the share of $22 \%(\mathrm{~N}=15)$ and agencies with $0-2$ employees and share of $21 \%(\mathrm{~N}=14)$. The distribution of agencies considering the number of employees is shown in the Figure 1.

\section{Figure 1. Agencies considering the number of employees}

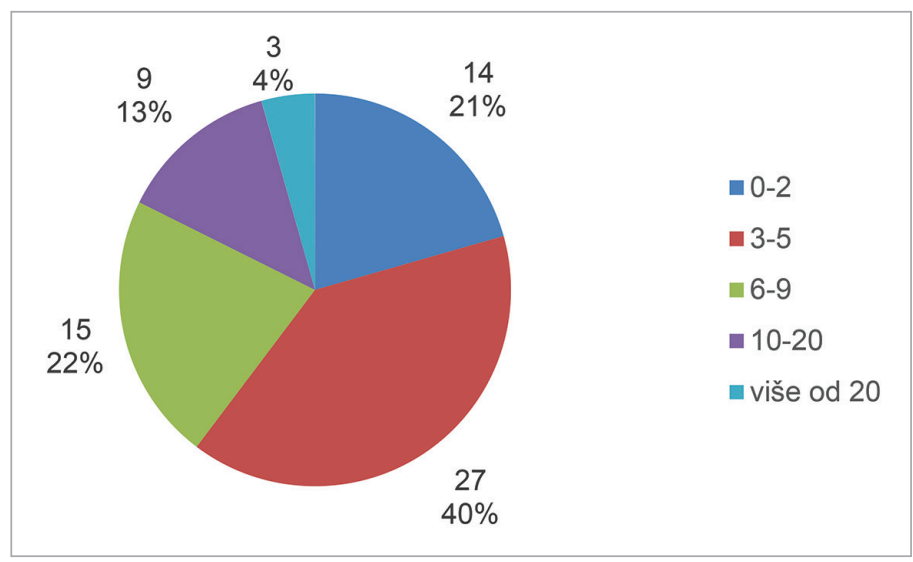

Source: Authors' work

During the data collecting agencies have been asked whether they use any kind of KM or other agency programmes in their daily business and $60 \%(N=41)$ responded positively. Figure 2 shows that for agencies with fewer employees, the degree to which they use agency programmes is far lower than for larger agencies. Moreover, there is a clearly visible link in which a larger agency (with more employees) will be more prone to use some of the agency programmes, while smaller (with fewer employees) will be more reluctant to use agency programmes. Only $14 \%$ of agencies with 2 or fewer employees use programmes, while the usage rate is $59 \%$ for agencies with 3 to 5 employees. 
Figure 2. Usage of agency software related to number of employees

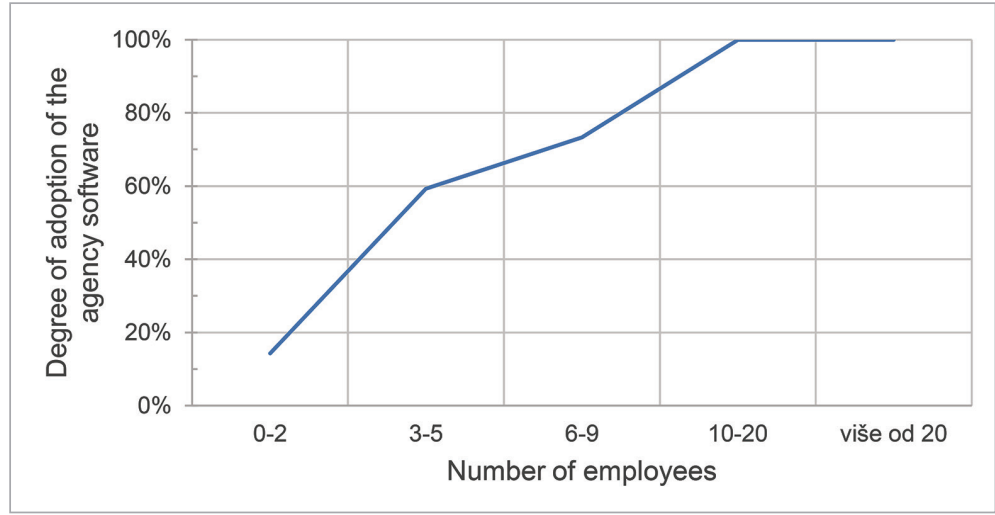

Source: Authors' work

Such a behaviour towards the usage of agency programmes can be interpreted by the lack of human and financial resources at their disposal for that purposes. 27 of total number of respondents, as it is shown in the Figure 3. do not use the agency programmes in their business operations. As reason most of them declare that the programmes are too expensive ( $N=11 ; 41 \%$ ) Only $19 \%$ (5 out of 27 ) stated that their agency was still too small to use the agency programmes). The same percentage claim that they did not find an adequate programme to meet the agency's needs again bringing the issue of price into focus, which leads to the conclusion that in as many as $52 \%$ of cases the price of the program was crucial in deciding not to use an agency programme.

Figure 3. Reasons why agencies do not use software

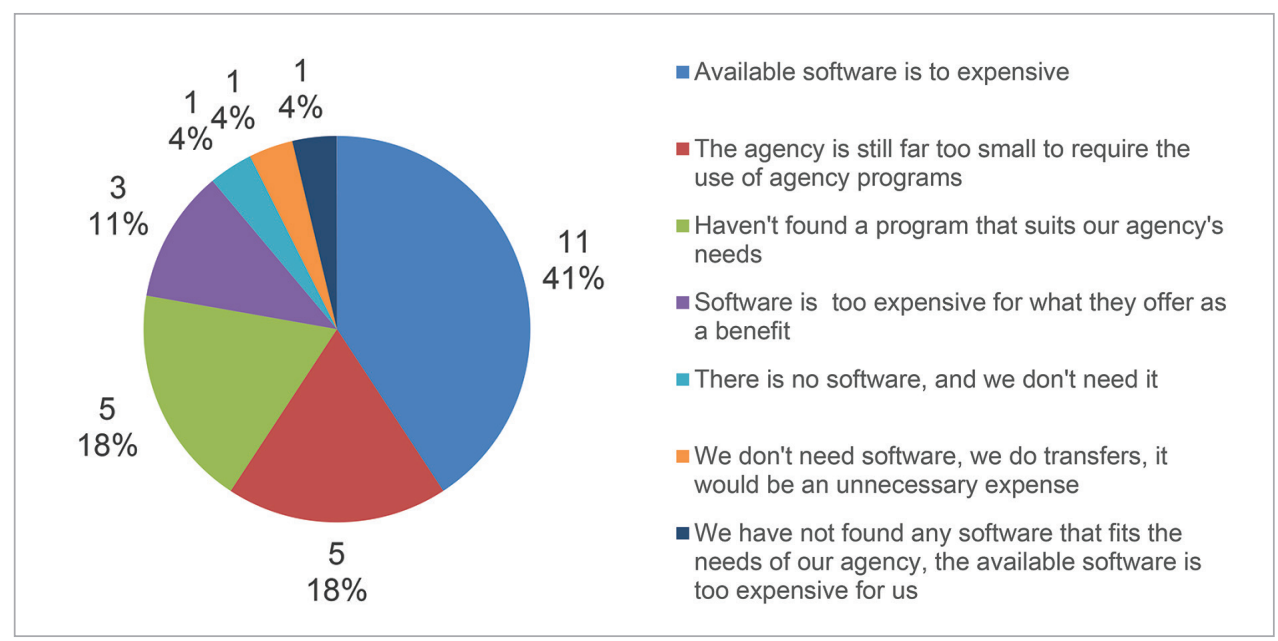

Source: Authors' work 
All the agencies that have stated that they do not use agency programmes in their business, have declared that they use office tools (Word, Excel, file sharing, etc.) as a replacement. The only difference is that 15 (56\%) of them claim that they would rather use a good agency programme, while 12 (44\%) think that available office tools satisfy their needs well enough (see Figure 4).

\section{Figure 4. Use office tools as alternative for an agency program}

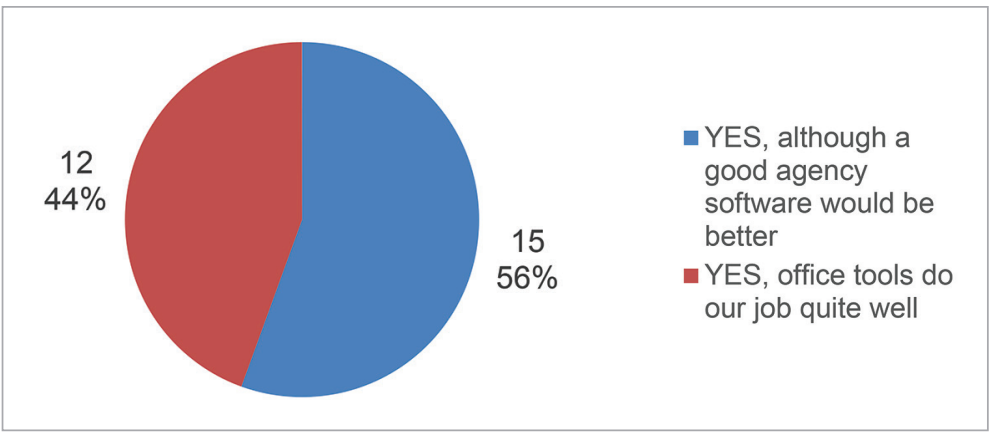

Source: Authors' work

Instead of procurement of the agency programme on the ready-made solutions market, agencies have also been asked about the possibility to develop their own solution. The vast majority, $18(66 \%)$, think that developing their own solution is too expensive, and only $3(11 \%)$ have plans to do so (see Figure 5).

\section{Figure 5. Developing own agency software}

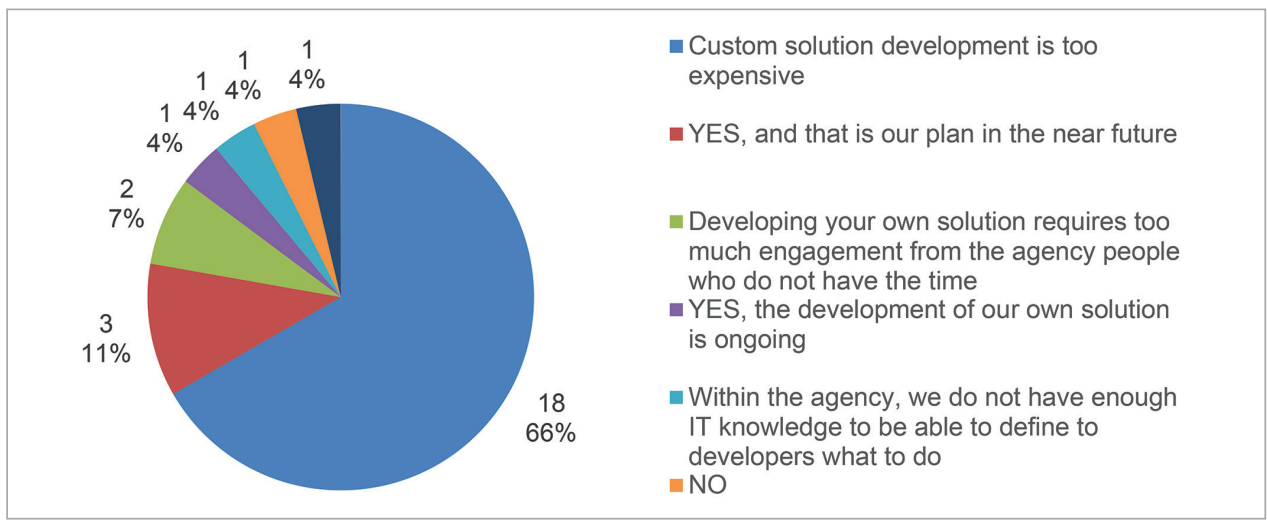

Source: Authors' work

As a benefit of using the programme, agencies primarily see the facilitation of data transfer and communication with other systems (15 agencies; $27 \%$ ). This attitude is very likely conditioned by the agency's need to make its products and services available through electronic distribution channels. Indeed, all 15 agencies that have expressed this atti- 
tude are in the business of accommodation, and their success in selling these capacities is highly dependent on their ability to successfully manage sales channels. As another important aspect, agencies recognize preventing errors and glitches. 14 agencies (25\%) consider certain control of processes when entering data and creating documents as a crucial factor for adopting agency programmes. The processes regarding information sharing and collaboration within an agency are relatively low on the priority list, and only 7 out of 56 agencies (12\%) identify this concept as crucial for success. The reasons and motivation to use agency software is shown in the Figure 6.

\section{Figure 6. Motivation to use agency software}

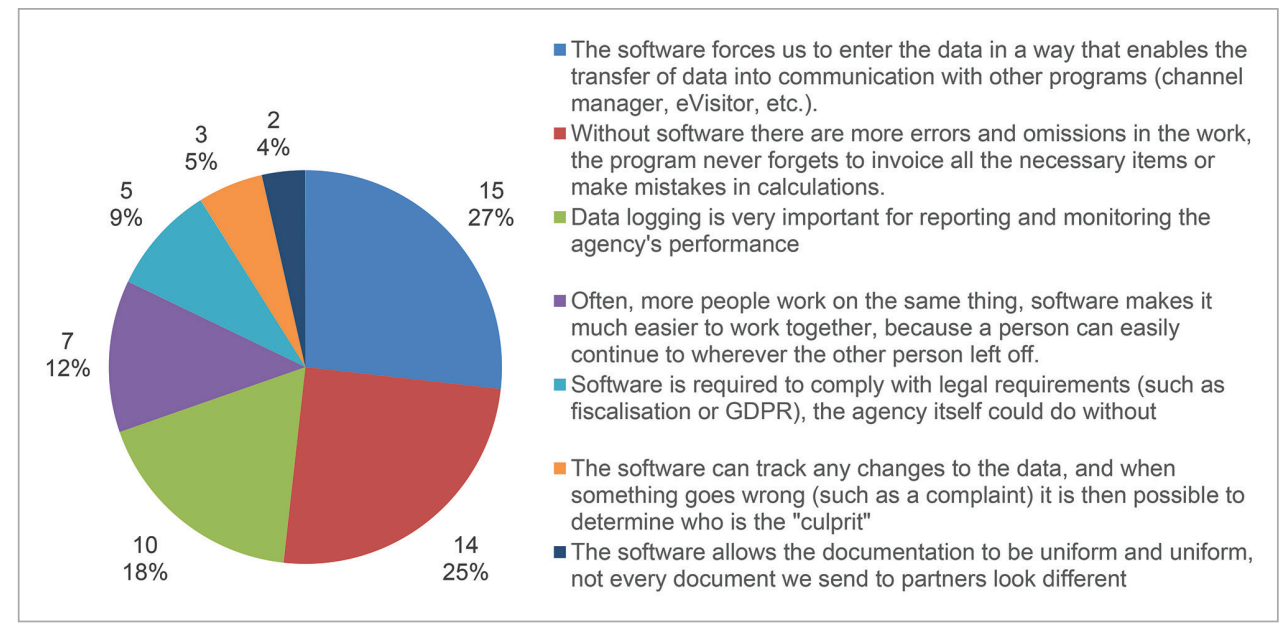

Source: Authors' work

In order to determine the degree of adequacy of the system in use at the agencies, a GAP analysis has been made to determine the difference between the system functionality currently used by agencies (only agencies using one of the programmes are analyzed) and the functionality that agencies express as desirable in describing their "ideal" system. The results are shown in the Figure 7. 
Figure 7. Missing functionalities

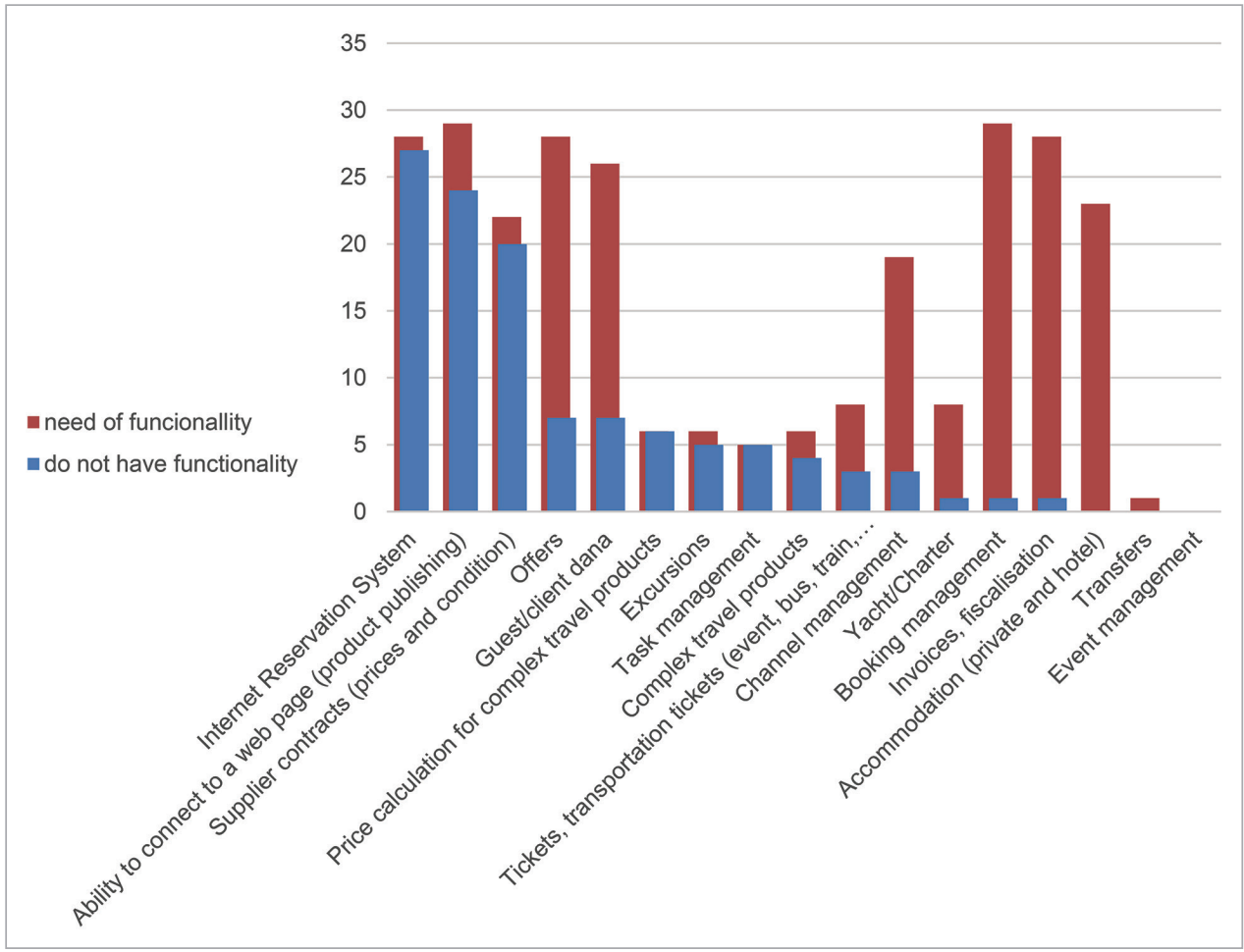

Source: Authors' work

The analysis reveals that at the top of the list of functionalities, which agencies are lacking, is connectedness with online business. 27 out of 29 agencies using some of the systems (93\%) state that the programmes they use lack online booking system functionality. Respondents want their online booking system and data recorded within the agency to be interconnected. $24(83 \%)$ of the agencies think the connection of their business system with web site is not satisfactory. 22 small agencies have stated that they need the functionality of storing purchase prices and contractual terms with suppliers, but even 20 of them lack it in the program they are currently using, which is indirectly related to knowledge management (knowledge of contracts and conditions under which procurement takes place).

\section{CONCLUSION}

This paper explores how and to what extent tourist agencies use methods and tools to manage information and knowledge, as well as whether there is room within their adopted practices for the advancement and realization of underutilized potentials

Hypothesis 1 and 2 have been corroborated by analyzing the data collected through the online questionnaire, and it was proved that: 
- agencies recognize the usefulness of a knowledge management system,

- $\quad$ agencies do use knowledge management systems in specific business segments, and

- there are detected reasons why agencies may not use knowledge management systems

After processing the collected data, the characteristics of an "ideal" agency-tailored knowledge management system that meets the requirements of small travel agencies have been determined and described, which proves Hypothesis 3. Additionally, an analysis of the available agency KM systems in terms of existing functionalities required by agencies has been made.

In general, there are three major factors preventing agencies in adopting some commercial KM applications or developing their own solutions;

- Agencies perceive KM solutions of any kind as too expensive and to some extent beyond their reach.

- Office tools are perceived as an acceptable alternative, either by completely replacing the agency programmes or as being a necessity, used until the agency becomes mature and big enough to adopt an agency programme.

- The programmes already used for the agency business activities are not fully adequate. The research indicates deficiencies in the area of connecting $\mathrm{Km}$ solutions with the agency's web portal (online sales), and also in the functionality related to storing and using the procurement data and the conditions under which the procurement takes place. 


\title{
PRIMJENA INFORMACIJSKIH SUSTAVA ZA UPRAVLJANJE ZNANJEM U MALIM TURISTIČKIM AGENCIJAMA
}

\author{
Dean Nižetić, spec. inf. mgmt. \\ Veleučilište VERN \\ Trg bana Josipa Jelačića 3, Zagreb, Croatia \\ e-mail: dean@nizetic.com \\ dr. sc. Anton Florijan Barišić, prof. v. š. \\ Veleučilište VERN \\ Trg bana Josipa Jelačića 3, Zagreb, Croatia \\ e-mail: afbarisic@chronos.hr
}

\section{SAŽETAK}

Brz razvoj tehnologija doveo je do pojave novih prilika za organizacije kao što je djelotvorno upravljanje resursima znanja za postizanje organizacijske uspješnosti. Svrha ovog rada bila je utvrditi koriste li agencije sustave UZ dostupne na tržištu, koji su razlozi za njihovo usvajanje, te istražiti adekvatnost implementiranih sustava i definirati karakteristike „idealnih" sustava UZ za male organizacije, U tom je smislu glavni cilj istraživanja bio istražiti razinu usvojenosti informacijske tehnologije za upravljanje znanjem u malim turističkim agencijama s manje od 20 zaposlenih. Na temelju ankete provedene među malim turističkim agencijama na uzorku od 68 valjanih odgovora iz on-line upitnika, ovo istraživanje ocrtava položaj i trendove razvoja uporabe informacijskih sustava za upravljanje znanjem odgovarajući na sljedeća pitanja: (a) prepoznaju li agencije koristi od korištenja sustave upravljanja znanjem i u kojim segmentima svog poslovanja, (b) koje vrste sustava upravljanja znanjem koriste i u kojim poslovnim segmentima, (c) koji su razlozi da se sustavi upravljanja znanjem ne koriste? U istraživanju su korištene matematičko-statističke metode za analizu odnosa malog hrvatskog turističkog poduzeća prema korištenju suvremenih tehnologija radi poboljšanja njihovih poslovnih rezultata. Rezultati su ukazali i na razloge slabog usvajanja IT UZ rješenja u svakodnevnom poslovanju. Na temelju provedene analize predložena je okvirna specifikacija „idealnog" sustava UZ.

Ključne riječi: IT management, upravljanje znanjem, organizacija, organizacijska uspješnost, organizacijska djelotvornost

JEL klasifikacija: M15, M10, O39, L22, L25, M55 


\section{REFERENCES}

1. Assl, M. (2007). Knowledge Management in the tourism and leisure industry with the case study of the Austrian National Tourist Office within the European market (Master thesis). Gent Belgium: University Gent. Preuzeto s: https://lib.ugent.be/fulltxt/RUG01/001/414/625/RUG01001414625_2010_0001_AC.pdf

2. Baggio, R. \& Cooper, C. (2010). Knowledge transfer in a tourism destination: the effects of a network structure. The Service Industries Journal, 30(10), 1757-1771.

3. Barišić, A. F. (2013). Upravljanje znanjem i organizacijsko učenje. Veleučilište VERN'.

4. Buhalis, D. \& Law, R. (2008). Progress in information technology and tourism management: 20 years on and 10 years after the Internet - The state of eTourism research. Tourism management, 29(4), 609-623.

5. Casimir, G., Lee, K. \& Loon, M. (2012). Knowledge sharing: influences of trust, commitment and cost. Journal of knowledge management, 16(5), 740-753.

6. Ciampi, F. (2007). Knowledge Creation through Managerial Consulting, 7th Global Conference on Business and Economics, 12-14.10. 2007, Rome, Italy

7. Cooper, Ch. (2006). Knowledge management. Annals of Tourism Research, 33(1), pp. 47-64.

8. Dalkir, K. (2013). Knowledge management in theory and practice. Routledge.

9. Del Chiappa, G. \& Baggio, R. (2015). Knowledge transfer in smart tourism destinations: Analyzing the effects of a network structure. Journal of Destination Marketing \& Management, 4(3), 145-150.

10. Girard, J. \& Girard, J. (2015). Defining knowledge management: Toward an applied compendium. Online Journal of Applied Knowledge Management, 3(1), 1-20.

11. Hallin, C. A. \& Marnburg, E. (2008). Knowledge management in the hospitality industry: A review of empirical research. Tourism management, 29(2), 366-381.

12. Handžić, M., Durmić, N. (2015). Knowledge Management, Intellectual Capital and Project Management: Connecting the Dots. Electronic Journal of Knowledge Management, 13, 51-56.

13. Kakihara, M. \& Sørensen, C. (2002). Exploring knowledge emergence: from chaos to organizational knowledge. Journal of Global Information Technology Management, 5(3), 48-66.

14. La Rocca, G. (2012). Knowledge based engineering: Between Al and CAD. Review of a language based technology to support engineering design. Advanced engineering informatics, 26(2), 159-179.

15. Livi, C. (2008). Information Technology and Business Models in Tourism Industry, 8th Global Conference on Business and Economics, 18-12.10, 2008, Florence, Italy.

16. Maier, R. \& Hadrich, T. (2011). Knowledge management systems. In Encyclopedia of Knowledge Management, Second Edition (pp. 779-790). IGI Global.

17. Ministartsvo turizma Republike Hrvatske. (2018). Turizam u brojkama 2017. Zagreb: Ministartsvo turizma Republike Hrvatske

18. Mistilis, N. \& Sheldon, P. (2006). Knowledge management for tourism crises and disasters. Tourism Review International, 10(1-2), 39-46.

19. Musulin, J., Gamulin, J. \& Crnojevac, I. H. (2011). Knowledge management in tourism: The importance of tacit knowledge and the problem of its elicitation and sharing. In 2011 Proceedings of the 34th International Convention MIPRO (pp. 981-987). IEEE.

20. North, K. (2008). Upravljanje znanjem: vođenje poduzeća usmjereno prema znanju. Jastrebarsko: Naklada SLAP. 
21. North, K., Reinhardt, R., Schmidt, A. (2004). The Benefits of Knowledge Management: Some empirical evidence. OKLC 2004 Conference. Innsbruck.

22. Omona, W., van der Weide, T. \& Lubega, J. (2010). Using ICT to enhance knowledge management in higher education: A conceptual framework and research agenda. International Journal of Education and Development using ICT, 6(4), 83-101.

23. Omotayo, F. O. (2015). Knowledge Management as an important tool in Organisational Management: A Review of Literature. Library Philosophy and Practice, 1(2015), 1-23.

24. Scott, N. \& Laws, E. (2006). Knowledge sharing in tourism and hospitality. Journal of Quality Assurance in Hospitality \& Tourism, 7(1-2), 1-12.

25. Shaw, G. \& Williams, A. (2009). Knowledge transfer and management in tourism organisations: An emerging research agenda. Tourism management, 30(3), 325-335.

26. The new economy: beyond the hype: final report on the OECD growth project (2001). Paris: Organization for Economic Cooperation and Development.

27. Tribe, J. \& Liburd, J. J. (2016). The tourism knowledge system. Annals of Tourism Research, 57, 44-61.

28. Weaver, D. B. (2000). A broad context model of destination development scenarios. Tourism management, 21(3), 217-224.

29. Wielicki, T. \& Arendt, L. (2010). A knowledge-driven shift in perception of ICT implementation barriers: Comparative study of US and European SMEs. Journal of Information Science, 36(2), 162-174.

30. World Tourism Organization. (2007). A Practical Guide to Tourism Destination Management. Madrid: World Tourism Organization.

31. Zaei, M. E. \& Zaei, M. E. (2014). Knowledge management in hospitality and tourism industry: A KM research perspective. Information and Knowledge Management, 4(9), pp. 114-122 